https://helda.helsinki.fi

\title{
Empire and International Law: The Real Spanish Contribution
}

\section{Koskenniemi, Martti}

2011

Koskenniemi , M 2011 , ' Empire and International Law: The Real Spanish Contribution ', University of Toronto Law Journal , vol. 61, no. 1, pp. 1-36.

http://hdl.handle.net/10138/231005

acceptedVersion

Downloaded from Helda, University of Helsinki institutional repository.

This is an electronic reprint of the original article.

This reprint may differ from the original in pagination and typographic detail.

Please cite the original version. 
The Spanish Scholastics of the sixteenth century are generally known as the precursors of Hugo Grotius in the application of natural law and the law of nations (ius gentium) to the political relations of early modern states. Their writings on the American Indians have been read as especially significant for the formation of the humanist-colonialist legacy of (European) international law. I have no quarrel with these views. This essay will, however, claim that the principal legacy of the Salamanca scholars lay in their development of a vocabulary of private rights (of dominium) that enabled the universal ordering of international relations by recourse to private property, contract, and exchange. This vocabulary provided an efficient articulation for Europe's 'informal empire' over the rest of the world and is still operative as the legal foundation of global relations of power.

Keywords: international law/ius gentium/private rights/Francisco de Vitoria (1483/92-1546)/Domingo de Soto (1494-1560)/early modern natural law/scholasticism

I Introduction: The empire of private law

'Empire' and 'imperialism' are powerful words - though they may have lost some of their force from constant iteration in practically every discussion of global problems, especially among discussants displaying political realist sensitivities; which is probably why these words have traditionally not had too much of a presence in international law. If they do occur, it is usually in order to mark some contrast to law, perhaps an alternative to law (and, of course, worse than it) as a way of organizing international relations. The state of affairs has changed in recent years, however, largely as a result of postcolonial influences as well as of the omnipresent desire to discuss the us position in the world with a vocabulary that transcends the boundary between analysis and criticism. But it is clear that 'empire' has entered international law, not only to provide an external contrast to law in the dangerous world of politics, but as part of international law itself.

* Professor of International Law, University of Helsinki; Hauser Global Professor of Law, NYU School of Law

$\uparrow$ This article is based on the Cecil AWright Memorial Lecture delivered at the University of Toronto on Thursday, 28 January 2010. I would like to thank Olivier Barsalou for assistance with the article. 
This was always suggested in the work of realism-inspired legal historians such as Wilhelm Grewe, whose Epochs of International Law joins Carl Schmitt's work on the Nomos of the Earth in unabashedly assuming that law and legal change are an effect of hegemonic struggles so that the law of the 'Spanish age' may be contrasted with that of the 'French age,' for example. ${ }^{1}$ For Grewe, as for Schmitt, empire lies in the realm of politics and the state. These provide the ground from which, to use Schmitt's metaphor, cultural influences and law then 'radiate' to the imperial periphery. More recent critics, who have pointed to the 'colonial origins of international law,' have also identified these influences in the way international law has been used by powerful Western states to exercise their political domination in the world. Spanish, French, and AngloAmerican imperialism have thus made their way into the analyses of past and present international law from both the political right and the political left.

But clearly, this is not the only way to think about the operation of imperialism within the law. While it is understandable that public international lawyers and historians have traditionally focused on the public activities of sovereigns and on the formal imperial relationships that may be embodied in international law rules and institutions, these are only a small part of imperial relations, one arguably less important than the relations that operate through the universal functioning of such private-law rules as those concerning property and contract. Lawyers are, of course, familiar with the distinction between public and private international law, but the latter has normally been understood to cover only a very limited set of rules and procedures having to with the relations of national legal systems to each other. And while fields such as lex mercatoria or transnational law have aimed to include a wider set of materials having to do with the global operation of the economic system, they have usually done this at the cost of losing the political edge that attaches to studies of empire and imperialism.

In this essay, I will join colleagues who have worked to analyse relations of private ordering within such aspects of public international law as the laws of war and intervention, post-conflict governance, arbitration, trade and investment, and so on. I shall aim to do this by focusing on the great interest that men who are regularly thought of as the originators of international law also had in capturing the global operation of private relations of domination in their analyses and theories. My claim is that, by concentrating merely on what they say on such public law issues as

1 Wilhelm Grewe, Epochs of International Law, translated and revised by Michael Byers (Berlin: Walter de Gruyter, 2000); Carl Schmitt, Nomos of the Earth in the International Law of Jus Publicum Europaeum, translated by GL Ulmen (New York: Telos Press, 2003). 
territory, jurisdiction, and formal war and by ignoring those aspects of their work that deal with the universal operation of property and contract, we receive a truncated and one-sided image not only of what they were doing but of the nature of the legal system that was emerging at the time when they were writing and that has persisted much more powerfully as part of global history than did any formal empire. The essay will thus also make the point that the cantonization of different aspects of the global operation of legal rules in different sub-disciplines has a dramatically negative effect on our ability to understand how law actually channels global relationships of domination.

\section{The question of the Spanish origins}

Culturally speaking, modern international law arose in the last third of the nineteenth century. It emerged as part of the liberal internationalism of the 1860s and 1870s and the turn by leading European powers Britain, France and somewhat belatedly Germany - to formal empire, the annexation of colonies under the aegis of a civilizing mission. When a group of men for the first time recognized each other as colleagues in a profession called 'international law' with the establishment of the Institut de droit international in 1873, one of their first projects was to determine the rules that would enable the 'Scramble for Africa' to be taken to a peaceful conclusion. They supported King Léopold's ventures in the Congo - some of the key members of the Institut were close advisers to the king of the Belgians - and many of them acted as advisors to their national delegations at the 1885 Congress of Berlin where, under Chancellor Bismarck's watchful eye, they distributed among themselves pieces of what King Léopold once called 'ce magnifique gateau' of Africa.

The early international lawyers were liberals who supported the turn to formal empire in order to protect the natives from the greed of colonial companies and ensure the orderly progress of the civilizing mission. They were imperialists not irrespective of their liberalism but as a consequence of $i t$ : they were imperialists for the same reason that they endorsed free trade and advocated penal reforms, new labour and social legislation, and sometimes women's rights and the spread of representative government in Europe. They were usually Protestants - Belgians, Dutchmen, Englishmen, and Germans, later joined by Americans and Scandinavians. There were moderate Catholics, too, some Frenchmen, a few Italians. As part of their gentle civilizing ethos, they were antipapists. The main operator behind the Institut, for example - Gustave Rolin-Jaequemyns from Ghent - was a minister of education in Belgium's liberal government who removed religious teaching from the schools. And the most famous member of the new profession, Johann 
Caspar Bluntschli from Germany, was a staunch ally of Bismarck's Kulturkampf. ${ }^{2}$

So it was no surprise that they contrasted their civilizing mission with what they had learned of the conduct of the Spanish after the arrival of Columbus at Hispañola in 1492. All of them referred to the Leyenda negra (black legend) - the account of Spanish imperialism first offered by William of Orange in an ad hominem attack on Philip II in support of the rebellion in the Low Countries in the late sixteenth century. Today, we are familiar with its themes: Torquemada and the Inquisition; Cortés's destruction of the Aztec empire, Pizarro's slaying of the Inca king Atahualpa at the battle of Cajamarca, and the plundering of Inca gold; the depopulation of the Caribbean and genocide in New Spain (Mexico) and New Castile (Colombia). Modern international law was born as liberal empires turned to formal annexation. But its ideological base lay in its righteous critique of the Spanish empire. ${ }^{3}$

But the founders of the profession found among the Spanish voices some they could associate themselves with. In the 1880s, the Belgian legal historian Ernst Nys first pointed to a tradition of late scholastic teaching in Spain, especially at the University of Salamanca, which had been critical of the conduct of the Conquista and actively propagated domestic and universal laws to control and direct its course. ${ }^{4}$ Dominican theologians such as Francisco de Vitoria (1483/92-1546) aligned themselves with the more famous Bartolomé de Las Casas (1484-1566) in defence of the Indians, insisting on their humanity as well as their rights of property and jurisdiction. In the 1920s and 1930s, these men were celebrated as precursors of the new profession by the American internationalist James Brown Scott (1866-1943), assistant to the Secretary of State, Elihu Root, an enthusiast of arbitration and the League of Nations. Scott admired the humanitarian impulse behind the teachings of these Spaniards and especially their propensity to discuss empire in light of the law of nature and of nations, ius gentium. Scott gave particular attention to the two public lectures (relectiones theologicae) given by Vitoria in 1538 and 1539 in Salamanca, which defended Indian rights while simultaneously laying out rules for Spanish trade and proselytizing in the newly conquered territories. Here, Scott suggests, was an exemplary case of a conscientious publicist turning against the

2 This period is discussed in my The Gentle Civilizer of Nations: The Rise and Fall of International Law 1870-1960 (Cambridge, UK: Cambridge University Press, 2001).

3 For an overview, see Joseph Pérez, La leyenda negra (Madrid: Gadir, 2009).

4 Ernest Nys, Les droits des Indiens et les publicistes espagnols (Brussels: P Weissenbruch, $1890)$; Ernest Nys, 'Les publicistes espagnols du XVI ${ }^{\mathrm{e}}$ siècle et les droits des Indiens' (1889) 21 Revue de droit international et de législation comparée 532. 
excesses of his own country in the interests of the greater good of humanity. ${ }^{5}$

Since that time, international lawyers have seen their own humanitarian sentiments, their legalism, and their sense of civilizing conduct reflected in the part of the Spanish renaissance that resuscitated and modified the ideas of Thomas Aquinas (1225-74) to formulate an intellectual response to the challenges of an expanded but religiously split world. No wonder that, during the Franco era, Spanish jurists grasped at the paradox that liberal imperialists were deriving their ideology from orthodox Catholic thought. From the 1950 s to the 1970 s, in the United States and elsewhere, a new image of Spanish imperialism was slowly emerging, in which the focus shifted from the actions of the conquistadores to the efforts of the crown of Castile to regulate the process of colonization, including by prohibiting the use of slave labour and officially allowing the Indians to live in their communities under their native caciques. Lewis Hanke's 1949 classic, The Spanish Struggle for Justice in the Conquest of America, is typical of this literature. ${ }^{6}$ As its title suggests, it highlights the good intentions of the Spanish crown and the influence of Dominicans such as Las Casas and Vitoria in the formation of official policy, laying the main blame on the ruthlessness of single conquistadores such as Cortés and Pizarro, encomenderos and colonial administrators adopting the attitude 'Obedezco pero non cumplo (I obey but do not comply)' to laws sent in from Castile. ${ }^{7}$

The influence of these scholars on Spanish colonial laws was undeniable and persistent. Already in 1535, before Vitoria had given his famous public lectures and even before Pizarro's ships loaded with Inca gold had arrived in Seville, his younger colleague Domingo de Soto (1494-1560), holder of the Visperas chair at Salamanca, had publicly admitted that he had no idea on what basis the Spaniards could exercise jurisdiction over the Indians. ${ }^{8}$ Soto later became the chairman-rapporteur at the

5 See James Brown Scott, The Spanish Origins of International Law: Francisco de Vitoria and His Law of Nations (Oxford: Clarendon Press, 1934). For a discussion, see Christopher $\mathbf{R}$ Rossi, Broken Chain of Being: James Brown Scott and the Origins of Modern International Law (The Hague: Kluwer Law International, 1998).

6 Lewis Hanke, The Spanish Struggle for Justice in the Conquest of America, with a new introduction (University Park, TX: Southern Methodist University Press, 2002). See further the recent work of the school's main historiographer, Luciano Pereña, $L a$ idea de justicia en la conquista de América (Madrid: Mapfre, 1992) [Pereña, La idea de justicia].

7 Henry Kamen, Spain 1469-1714: A Society of Conflict, 2nd ed (London: Longman, 1996) at 160 .

8 Domingo de Soto, Relección 'De dominio.' Edición critica y traducción, con introducción, apéndices e indices, ed by Jaime Brufau Prats (Granada: Universidad de Granada, 1964) $§ 34$ (165): ‘. . . sed accipere ultra hoc bona illorum aut subiicere imperio nostro, no video unde habeamus tale ius.' 
famous 1550-1 junta in Valladolid that was called upon to decide the dispute between Las Casas and the humanist scholar Juan Gines de Sepúlveda (1489-1573) on the question of Indian slavery. He also acted as confessor to the emperor Charles v and represented Spain for many years at the Council of Trent, where he arose as one of the foremost ideologists of the Counter-Reformation. In all relevant respects, his views on Indian-Spanish relationships are indistinguishable from those of Vitoria.

In 1553/1556, Soto published his massive tract De iustitia et iure, where he repeated the argument that he had already made in the 1535 lecture that the humanity of the Indians was on a par with that of the Spanish and that they enjoyed rights of jurisdiction and property like all other human beings. Neither the Spaniards nor the pope could exercise jurisdiction over the Indians, whose rights of jurisdiction and ownership were based in part on nature, in part on the consent of the relevant communities as they had once come together for the procurement of their own good. Never had there been any such universal meeting in which somebody was offered lordship over all the world. Moreover, the idea that the emperor might have inherited the rights of the Romans over all the world was simply ridiculous: not only had the Romans never possessed such jurisdiction in the New World - the argument that they still had it owing to their special virtue completely overlooked the fact that these possessions had been acquired by the force of arms, not through their intellectual or moral qualities. ${ }^{9}$

\section{School of Salamanca and the Indian question}

Vitoria and Soto were the originators of the 'School of Salamanca' - the remarkable group of theologians and jurists concentrated around

9 Domingo de Soto, De iustitia et iure libri decem/De la justicia y el derecho en diez libros, intro by PV Diego Carro, translated into Spanish by PM Gonzalez Ordonez (Madrid: Instituto de Estudios Politico, 1967) 4.4 .2 at 303-6 [Soto, De iustitia]. Soto was an active participant in the Council of Trent, where he became known for his defence of the traditional doctrine of justification against Italian delegates who sometimes supported views closer to those of the Protestants; see Juan Belda Plans, La escuela de Salamanca y la renovación de la teologia en el siglo XVI (Madrid: Biblioteca de autores cristianos, 2000) at 405-6 [Belda Plans, La escuela de Salamanca]. For Soto's biography, see generally ibid at 399-412. For Soto's teaching and publishing activity, see Jaime Brufau Prats, El pensamiento politico de Domingo de Soto y su conceptión del poder (Salamanca, Spain: Ediciones Universidad Salamanca, 1960) at 12-7. For a discussion of the way Soto based dominium in part on nature, in part on consent, see Annabel S Brett, Liberty, Right and Nature: Individual Rights in Later Scholastic Thought (Cambridge, UK: University Press 1997) at 137-64 [Brett, Liberty, Right and Nature]. 
Castile's oldest university from which their teaching spread to the Iberian peninsula and into the Americas in the course of the sixteenth and early seventeenth centuries. Inspired by a humanist interest in matters of social relevance, these men aimed to accommodate orthodox Thomism to aspects of the via moderna its originators had learned in Paris so as to deal with the tremendous political, economic, cultural, and religious changes they witnessed taking place around them. The life of the school is conventionally divided into three periods - that of the 'founders,' Vitoria and Soto; that of 'expansion,' whose representative figures would be the two Dominican professors, Pedro de Sotomayor (1500-64) and Bartolomé de Medina (1527-81) (the former also Professor at Valladolid), authors of large works on the Indies and on the theory of law and justice; and finally, that of the 'synthesis' carried out by men such as the Dominican Domingo de Bañez (1528-1604) and, of course, the Jesuit Francisco Suárez (1548-1617). The school's leading historiographer, Luciano Pereña, identifies altogether 125 larger synthetic works (usually in the Thomistic genres of De legibus, De iustitia et iure, or their derivatives) in this period as representative of the school's intellectual ambiance. ${ }^{10}$ These also include works by experts in canon and civil law, such as Martin de Azpilcueta (1491-1586) and Diego de Covarrubias (1512-1577). Likewise, even if the influential writings of the civil lawyer Fernando Vázquez de Menchaca (1512-59), another contemporary of Vitoria at Salamanca, are quite different in style from the latter's scholasticism, the eclectic, fact-oriented humanism

10 For this way of presenting the school, see Luciano Pereña, 'Estudio preliminaria: La tesis de la paz dinámica' in Francisco de Vitoria, Relectio de belli o paz dinamica, in Luciano Pereña et al, eds, Escuela Española de la paz: Primera generación 1526-60 (Corpus Hispanorum de Pace, vol 6) (Madrid: Consejo Superior de Investigaciones Cientificas, 1981) at 65 [Pereña, 'Estudio preliminaria']; and Pereña, La idea de justicia, supra note 6 at 125-34. Belda Plans, La escuela de Salamanca, supra note 9 at 155-69, who begins with Vitoria (1526) and ends with the death of Bañez (1604), concentrates on the school's theologians. His analysis relies on three criteria: (1) linkage to both Salamanca and Vitoria, (2) a focus on the renovation of theology, and (3) working in the tradition of the Summa of Aquinas. From this, two phases may be distinguished: first, a period of innovation extending from Vitoria to Bartolomé de Medina (1527-80), the 'father' of probabilism; then, from the time of Medina to that of Pedro de Herrera (1548-1630) and Bañez, the last occupant of the Prima chair, a more doctrinal phase, one characterized more by rivalry and confrontation (especially with the Jesuits), with less attention to humanist styles or themes. This approach excludes both jurists and Suárez (who never taught at Salamanca). The first phase is dominated by the 'three greats' - Vitoria, Soto, and Cano - and the second is less creative; ibid at 170, 178-82. For a new history that I have so far been able to consult only superficially, see Miguel Anxo Pena González, La escuela de Salamanca: De la Monarquía hispanica al Orbe católico (Madrid: Biblioteca de autores cristianos 2009). 
that he puts forward in his Controversiarum illustrium usuque frequentium libri tres (1564) nevertheless ends up endorsing positions that do not really differ from those of the rest. ${ }^{11}$

The views of these Spaniards on the rights of the Indians were quite homogeneous. As against the older theory that Indians were natural slaves put forward by one of Vitoria's Paris teachers, the Scotsman John Mair (1467-1550), they regarded the Indians as humans and thus, like all humans, born free. ${ }^{12}$ They also invariably rejected the view that the pope or the emperor might have rights of jurisdiction in the newly conquered territories. In the official view put forward in the notorious requerimiento that was supposed to be read to the Indians before war could be waged against them, the pope had 'donated' these lands to the rulers of Castile and Aragon. Soto, Vitoria, Las Casas, and all the rest completely rejected this view: the kingdom of Christ was not of the world and could not have been given to Peter or his followers to dispose of. Nor had the emperor - Charles $\mathrm{v}$ - any better right. Roman law did not apply to the Indians. Like Soto, Vitoria went meticulously through the unjust claims that the Spanish had made: mere infidelity did not deprive of the Indians of their rights - the contrary doctrine was, in fact, a Protestant heresy. Nor were the Indians any more mad than people who could be found in places in Spain. That they were sinners did not deprive them of their rights - after all there were many sinners among Christians, too, without this making them lose their property. ${ }^{13}$

These views are relatively well known and later theologians and jurists of the School of Salamanca supplemented them in different ways, usually

11 For the biography of Vázquez, see especially Kurt Seelmann, Die Lehre des Fernando Vazquez de Menchaca vom Dominium (Cologne: Heymanns, 1979) at 25-30. The life and (especially) fame of Vázquez is also treated in Ernst Reibstein, Die Anfänge des neueren Natur- und Völkerrechts: Studien zu den 'Controversiae illustres' des Fernandus Vasquius (1559) (Bern, Switzerland: Verlag Paul Haupt, 1949) at 19-27; and Camilo Barcia Trelles, 'Fernando Vázquez de Menchaca (1512-1569). L'école espagnole de Droit International du XVI ${ }^{\mathrm{e}}$ siècle' (1939) 67 Rec des Cours 430 at 433-42. The best recent analysis is that offered by Annabel Brett, Liberty, Right and Nature, supra note 9 at $165-204$.

12 This view, incidentally, was also shared by the infamous drafter of the so-called requerimiento, the legal counsel for the Spanish king, Juan López de Palacios Rubios (c 1450-1524), who not only accepted Indian ownership of property but even thought that the Indians could wage just war against the Spanish if the latter tried unjustly to deprive them of their goods; see Juan López de Palacios Rubios, De las Islas del Mar Océano (México: Fondo de cultura económica, 1954) at 61.

13 See Francisco Vitoria, 'On the American Indians' in Francisco Vitoria, Political Writings, ed by Anthony Pagden \& Jeremy Lawrance (Cambridge, UK: Cambridge University Press, 1991) 231 at 251-77 [Vitoria, 'On the American Indians'] [Vitoria, Political Writings]. 
in the Indians' favour. The Augustinian Alonso de Veracruz (1507-84), professor of theology at the University of Mexico, for example, noted in 1553 that the Indians had been in rightful possession of their property and that the Spanish had arrived as aggressors. ${ }^{14}$ The Dominican Domingo de Salazar (1512-94), the first Bishop of Manila, observed the range of arguments in 1583 and noted the 'condemnation by nearly all writers in Spain and even in the Indies, of the conquests that have been carried out against the Indians. ${ }^{15}$ Moreover, despite the reverence in which Vitoria was usually held, Las Casas and the famous Jesuit Luis de Molina (1535-1600), the father of 'Molinism,' criticized the broad basis on which he had advocated the ius communicandi to justify the penetration of Indian lands. No European nation would allow large numbers of armed foreigners freely to enter their countries. Moreover, the Spanish themselves had expelled the Jews and the Moriscos just a few years earlier. The ruler must, if peace and tranquillity require this, prevent foreign traders and travellers from having access to his realm. ${ }^{16}$

But even if most Spaniards agreed that the conquest had originally taken place in an unlawful manner, this did not lead them to advocate a speedy end to the presence of Spain in the New World. Soto, Vitoria, Molina, and others agreed that the Spanish had to remain as trustees in order to protect the innocent and to continue preaching the gospel. If the Indians persisted in human sacrifice or the harassment of priests or those who had been converted, force could continue to be used against them. ${ }^{17}$ Leaving abruptly would undo the work of evangelization and make the Indians lapse into their barbaric ways, they assumed. Not everyone thought that this would necessitate permanent Spanish presence. At the beginning of the 1570s, the Bishop of Toledo, Bartolomé

14 Pereña, La idea de justicia, supra note 6 at 150-1.

15 Pedro Borges, 'Proceso a las guerras de conquista' in Juan de la Peña, De bello contra insulanos: Intervención de España en America, in Vidal Abril Castelló \& Luciano Pereña, eds, Escuela Española de la paz: Segunda generación - Posición de la Corona (Corpus Hispanorum de Pace, vol 10) (Madrid: Consejo Superior de investigaciones cientificas, 1982) at 24 [Peña, De bello contra insulanos] [translated by author].

16 'Thus all people, towns, communities or autonomous kingdoms may, at the discretion of their leader, act in a way that is in accordance with peace and tranquility ... To this end, he may deny entry into his territory, his province, or his town to anyone who would like to do trade or sell goods by establishing himself there'; Las Casas, De thesauris in Peru, cited in Francois Courtine, Nature et empire de la loi: Études suaréziennes (Paris: Vrin, 1999) at 137-8 [translated by author]. See also Dieter Janssen, 'Theorie der gerechten Krieges' in Frank Grunert \& Kurt Seelmann, eds, Die Ordnung der Praxis: Neue Studien zur spanischen Spätscholastik (Tuebingen: Max Niemeyer Verlag, 2001) at $230-1$.

17 Vitoria, 'On the American Indians,' supra note 13 at 291-2. 
de Carranza (1503-1576), estimated that it would take perhaps another 16 to 18 years for the work of civilization to be permanent so that the Spaniards might be able to leave. ${ }^{18}$

Today, scholars such as Antony Anghie, China Miéville, and Robert Williams argue with force that the Salamancans took back with the left hand what they gave away with the right. The legal bases for the European presence in the Indies granted them everything they needed, furnishing a legal rationale for colonization and providing for the needs of the empire. Even at their most appealing, the Spaniards' arguments remained paternalistic and failed to respect Indian identity, never for a moment treating them as equal to Europeans. In fact, the argument goes, the Spaniards initiated the European practice of conducting colonialism and subjugating non-European cultures under a rhetoric of civilization and trusteeship. ${ }^{19}$

Perhaps unsurprisingly, this postcolonial reading of the Secunda Scholastica was met recently with a liberal retort from Georg Cavallar and Pablo Zapatero, both of whom focus on the good intentions of the Spaniards and their personal courage..$^{20}$ After all, the emperor did react in 1539 with a letter to the principal of the Convent of San Esteban, where both Vitoria and Soto were residing, to prevent their teaching and to destroy their manuscripts. ${ }^{21}$ Without their persistence, we might not have known much about the plight of the Indians. However, by that time, the famous campaign begun by Father Montesinos with a sermon on Hispañola that shocked churchgoers in 1511 had already spread everywhere in the Spanish realm, and the emperor's reaction neither significantly tempered the Dominicans' campaign nor occasioned a serious breach between them. Just two years later, Vitoria was again advising Charles on matters involving Indian conversions in

18 Luciano Pereña, 'La intervención de Espana en America' in Peña, De bello contra insulanos, supra note 15 at $130-4$.

19 Antony Anghie, Imperialism, Sovereignty and the Making of International Law (Cambridge, UK: Cambridge University Press, 2004) at 13-31; China Miéville, Between Equal Rights: A Marxist Theory of International Law (Leiden: Brill, 2005) at 173-8; Robert A Williams, Jr, The American Indian in Western Legal Thought: The Discourses of Conquest (New York: Oxford, 1990) at $96-107$.

20 See Georg Cavallar, 'Vitoria, Grotius, Pufendorf, Wolff and Vattel: Accomplices of European Colonialism and Exploitation or True Cosmopolitans?' (2008) 10 Journal of the History of International Law 181; Pablo Zapatero, 'Legal Imagination in Vitoria: The Power of Ideas' (2009) 11 Journal of the History of International Law 221 especially at 267-71 (on Antony Anghie and Brett Bowden).

21 Jean-Francois Courtine, 'Vitoria, Suárez et la naissance du droit de nature moderne' in Alain Renaut, ed, Naissances de modernité: Histoire de la philosophie politique, t 2 (Paris: Calmann-Lévy, 1999) at 128; Luis Frayle Delgado, Pensamiento humanista de Francisco Vitoria (Salamanca, Spain: San Esteban, 2004) at 42-3. 
Mexico. ${ }^{22}$ Neither Vitoria nor the much more polemical Las Casas had any real doubt about the essential justice of the Spanish staying in the Indies in order to carry out the work of evangelization. Vitoria also rejected the French claim that the pope could not grant a monopoly for the Spanish to engage in activities of conversion. Indeed, he argued, even as the pope could not grant dominium, surely he could or even should - coordinate evangelization to the best of his ability. ${ }^{23}$ The arguments of Vitoria, Soto, and their successors provided a more orderly basis for colonization, which is why they were taken seriously in successive acts of imperial legislation - even as, in the face of the vigorous protests of the encomenderos, very few of the laws were actually enforced.

These are the arguments as to the Spanish contribution to international law and empire that we usually cite. They continue the polemic of the Leyenda negra. But, to me, they seem to neglect the complexity of the moment and the continuing ambivalence of humanitarianism. As Vitoria began teaching, there was no clear view of where the Spanish (or Castilian) interests lay or what the position of the Church ought to be. There was no uniform view among theological and secular authorities as to right conduct in, or relations with the inhabitants of, the New World. ${ }^{24}$ The Spaniards' 'universalism' was so open-ended that it could be and was used to support varying and often contradictory policies. Whatever the vocabulary used to describe it - evangelization, trusteeship, trade, civilization, development - the mere fact of their supporting a presence in foreign lands is an insufficient basis for judging where positions were developing, and it is unclear where the interests of the different protagonists lay. Love is often difficult to distinguish from a desire to dominate - which is not to say that no distinction should be made between them..$^{25}$

But I would like to suggest that the principal Spanish contribution is not in those express arguments but in the development of a whole vocabulary that has since come to delineate the imperial dimensions of international law. At the heart of this vocabulary stand three notions already familiar from Roman law and medieval Christianity - dominium, ius gentium, and the bellum iustum. I would like to suggest that the most

22 Pereña, La idea de justicia, supra note 6 at 90-2; Luciano Pereña, La Escuela de Salamanca: Proceso a la conquista de América (Salamanca: Caja de Ahorros y Monte de Piedad, 1986) at 29-30.

23 Vitoria, 'On the American Indians,' supra note 13, $3.2 \S 10$ (284); Pereña, 'Estudio preliminaria,' supra note 10 at 50-1.

24 Francisco Castilla Urbano, El pensamiento de Francisco de Vitoria: Filosofía, política e indio américano (Barcelona: Anthropos, 1992) at 317-23.

25 For useful reflection on this theme, see Tzvetan Todorov, The Conquest of America: The Question of the Other (New York: Harper \& Row, 1984). 
important Spanish contribution to the practice of empire lies in the recovery of those three notions and in giving them a meaning through which it was possible to react not only to the duda Indiana - the concerns of conscience raised by the Spanish activities in the Indies - but to three further transformations that took place in the period: the formation of centralized political communities - states - that demanded absolute loyalty from their citizens; the emergence of a global economic system based on private ownership and the search for profit; and continuous warfare, not only against the infidel, but among Christian rulers themselves. The notions of dominium, ius gentium, and the bellum iustum were now deployed to give a legal and moral articulation to the transformations of early modernity that disturbed the consciences of contemporaries - an articulation that, as I will argue, continues to give a distinctly imperial structure to the most significant global laws and practices of the present age.

\section{Dominium and ius gentium}

Let us start with two Latin notions with a long legal pedigree, dominium and ius gentium. When Columbus left for the New World in 1492, no serious debate had arisen on the legal basis of his action. Potential problems had been resolved in the Treaty of Aleaçhas and Toledo of 1479-80, where Portugal abandoned its claims to the Canaries in exchange for the Spanish agreeing to respect Portuguese trade in Africa. ${ }^{26}$ Spain's title was derived from the Siete partidas ${ }^{27}$ that embodied the Roman law notion of islands' belonging to their first occupant in accordance with the rules of the occupation of the sea in which the island was found..$^{28}$ The famous mediation of the pope was only required as Portugal claimed the islands as part of the Azores. The line established in the pope's five letters, which include the Inter caetera of 5 May 1493, was slightly amended and then reaffirmed by the Treaty of Tordesillas a year later. ${ }^{29}$ The aim of Columbus's voyage had been exclusively economic. Evangelization had become part of the plan only through Queen

26 For the treaty, see John H Parry \& Rachel Keith, eds, New Iberian World: A Documentary History of the Discovery and Settlement of Latin America to the Early 17th Century, vol 1 (New York: Times Books, 1984) at 266-71.

27 Siete partidas, pt 3, title 28, law 29.

28 Michèle Escamilla-Colin, 'La question des justes titres - Repères juridiques: Des bulles Alexandrines aux Lois de Burgos' in Carmen Val Julian, ed, La conquête de l'Amérique espagnole et la question du droit (Fontenay-aux-Roses, France: Éditions ENS, 1996) 81 at $86-7$.

29 For these documents and those mentioned in the text following, see Parry \& Keith, supra note 26 at $271-80$. 
Isabella's famous 'testament' of 1504, which also spoke of the 'civilization' of the Indians. ${ }^{30}$

However, when the conquistadores returned from the Indies, many of them had grave doubts of conscience weighing upon them. By what right had they entered Indian communities, taken Indian goods, and waged wars on Indian tribes? So they flocked the Convent of St Esteban in Salamanca, where Vitoria and Soto lived, to confess their sins and to seek absolution. But what kind of a sin was it to take infidel property, to kill an Indian, and to occupy their land? Vitoria and Soto were religious scholars who needed to teach their students about the nature of the Spanish activities so as to prepare them to manage the sacrament of penance properly - were the Spanish activities sinful? and if so, how grave were their sins? Vitoria included a discussion of the Indian question, for the first time, in his lectures on the Summa theologiae of Aquinas of 1534-5 and in three famous public lectures (relectiones) held in 1537-9. In all of these, Vitoria agreed with the point made in Soto's 1535 lecture on dominium that the Indians were rightful owners of their property and that their chiefs validly exercised jurisdiction over their tribes. ${ }^{31}$

To make this argument, Vitoria's starting-point was that, under natural law, as affirmed by tradition going back to the Church fathers and Aquinas, no human being had natural dominion over another. Everyone was born free and property was held in common. ${ }^{32}$ Judged by natural law, however, not only the conquest, but every aspect of sixteenth-century European life - continuous warfare between European rulers, the emergence of an international system of trade based on private property, and the search for profit - was a moral abomination. One could not argue on the basis of natural law and hold the conquest, or indeed the existing government in Europe, as anything but a criminal conspiracy - as some, such as the notorious Juan de Mariana (1536-1624), suggested. Humans could be ruled only through force, Mariana would write, and nothing but the threat of tyrannicide would keep rulers from oppressing their subjects. ${ }^{33}$

30 Escamilla-Colin, supra note 28 at 92-3.

31 Vitoria, 'On the American Indians,' supra note 13, 2. 1-2 (252-64); and Francisco Vitoria, 'On the Law of War' in Vitoria, Political Writings, supra note 13, $1.3 \S 13$ (293 at 303-4) [Vitoria, 'Law of War'].

32 'Non cognoscit jus naturale differentiam inter homines, quia quidquid habet unus, est alterius de jure naturali' in Francisco de Vitoria, Comentarios a la Secunda secundae de Santo Tomás, t 3, ed Vicente Beltrán de Heredia (Salamanca, 1932-5) 62.1 at n 18 (75) [Vitoria, Comentarios].

33 Juan de Mariana, The King and the Education of the King (De Rege et Regis Institutione) in George A Moore, ed (Washington, DC: Country Dollar Press, 1948) chs 5, 6 at 
But Vitoria would not go that way; he lumped Machiavellian amoralism together with Protestant irrationalism. He was, thus, in a bind. On the one hand, he could not endorse a divinely created natural law - an ethic of love and common possession of everything - without undermining the policies of his emperor not only in the Indies but everywhere. On the other hand, he could not endorse the raison d'état either, without appearing to be just like the cynical apologists of power Luther had always accused Catholic churchmen of being. He needed a vocabulary that would accept the basic contemporary forms of territorial government, private ownership, and war but that would nevertheless restate the unity of humankind under God. This was provided to him by the twin vocabulary of dominium and ius gentium, the former covering a particular theory of forms of lawful human power, the latter extending that theory to be applicable everywhere.

The first question Vitoria had to pose was how, if natural law provided for freedom and communal ownership, was it at all possible for humans to rule over each other and to own property:

'But if it is the case that God made everything to be owned by all, and human beings are the common owners of everything by natural law, how and from which facts follows the division of things? [This division] is not made by natural law. For natural law is always the same and never varies. ${ }^{34}$

The obvious answer, given by Vitoria also in his famous relectio on the Indians, was that 'dominion and supremacy (praelatio) were introduced by human law, not natural law.' ${ }^{95}$ But this raised a further problem. How could merely human law deviate from a natural law whose origins lay with God? Hence the issue of concern: were the conquistadors, the traders, or indeed the emperor himself living in sin?

Vitoria resolved the problem in an impeccably scholastic way - by making a distinction; namely, a distinction between binding and merely recommendatory provisions of natural law. Freedom and common ownership were not based on a binding prescription ( praescriptio) but only a recommendation (concessio). They provided for common property but did not prohibit the divisio rerum - either in its public-law form of independent communities or in terms of private property. ${ }^{36}$ The division was undertaken by consensus - not by a formal consensus but by a 'virtual'

135-51. For a discussion of Mariana's pessimism, see Harold E Brown, Juan de Mariana and Early Modern Spanish Political Thought (Aldershot, UK: Ashgate, 2007).

34 'Sed si ita est quod deus fecit omnia communia omnibus, et homo est omnium dominus iure naturali, quomodo et unde facta est ista rerum divisio? [This division] non est facta de iure naturali: Patet quia ius naturale semper est idem et non variatur' in Vitoria, Comentarios, supra note 32, 62.1 at n 18 (74-5) [translated by author].

35 Vitoria, 'On the American Indians,' supra note 13, 2.1 (254).

36 Vitoria, Comentarios, supra note 32, 62.1 at n 20 (77). 
one ('non aliquo consensu formali, sed virtuali'); that is to say, by some taking pieces of land into use and then others following suit. Because this division was valid everywhere, it could not have been based on the civil law of this or that state. It had to have been undertaken by ius gentium. ${ }^{37}$

In his lecture on the Indians, Vitoria makes ius gentium do a lot of work, from dividing territories and properties to supporting the right to travel and to trade, to occupy terrae nullius, to enjoy the privileges of citizenship, and to despatch ambassadors. Yet he is frustratingly unclear about its legal nature. In an early lecture on civil power (1528), he speaks of the ius gentium as a law enacted by '[t]he whole world which is in a sense a commonwealth' - a kind of universal positive law in other words. ${ }^{38}$ Again, in the lecture on the Indians, he quotes the old definition by Gaius to the effect that the law of nations is 'what natural reason has established among all nations,' ${ }^{39}$ thus apparently collapsing ius gentium into natural law. In his treatment of war, Vitoria regards military action in self-defence as natural law, while admitting that even 'custom may establish the right and authority to wage war.' ${ }^{\prime}$

But Vitoria was not too concerned with legal classifications. In his lectures on the Summa, he admitted that whether ius gentium was called natural or positive was only a terminological issue. ${ }^{41}$ The important point - a point often overlooked by commentators - was that he followed Aquinas in locating the substance of ius gentium in the latter's systematic theology as part of 'justice' (iustitia) and not at all of the discussion of 'law' (ius). It was not a part of the external directives for human action but of the internal directives - of the virtues - and more specifically, of the other-related virtue of commutative justice. ${ }^{42}$ Now, commutative justice focused on individuals' (horizontal) relationships with each other and not, like distributive justice, on the (vertical) relations between the community and the individual. At the heart of commutative justice, Vitoria found the Roman law concept of dominium, in both of its senses as 'jurisdiction' and 'ownership.' If the prince had dominium over

37 Ibid, 62.1 at n 23 (79).

38 'On Civil Power,' Vitoria, Political Writings, supra note 13, $3.5 \S 21$ (40) [Vitoria, 'On Civil Power'].

39 Vitoria, 'On the American Indians,' supra note 13, $3.1 \S(278)$.

40 Ibid at 302.

41 Vitoria, Comentarios, supra note 32, 57.3 at n 2 (14), 62.1 at n 23 (79).

42 Or in other words, his was a subjective-right based definition of ius as a 'potestas vel facultas conveniens alicui secundum leges' (a power or faculty that belongs to somebody in accordance with the law); ibid, 62.1 at n 5 (64) [translated by author]. For a useful discussion of the theological context of Vitoria's theory of dominium, see Daniel Deckers, Gerechtigkeit und Recht: Eine historisch-kritische Untersuchung der Gerechtigkeitslehre des Francisco de Vitoria (Freiburg, Germany: Universitätsverlag, 1991) at 23-195. 
his commonwealth, this was because the community had delegated it to him. ${ }^{43}$ And it was through dominium that Vitoria would analyse, not only Spanish rights in the Indies, but also, and above all, the rights and duties of Spanish and foreign travellers and traders engaging in manifold commercial activities everywhere in the world. All humans had dominium over their actions as part of their natural liberty. It was in this that they resembled God. And the dominium they had as members of commonwealths and over their lives and their goods was a part of that liberty. On this theological basis, Vitoria and Soto derived a theory of individual rights (of dominium) as well as of their universal applicability as the foundation of just relationships between all human beings. ${ }^{44}$

In their lectures on the Indians, Vitoria and Soto concluded that all humans enjoy dominium in both of its senses, as public-law jurisdiction and as the private individual's right of property over things lawfully acquired. This right was based on natural law but the form of its specific realization had been decided by human communities through ius gentium. But even if its nature was historical and social, it was universally valid and thus fully applicable to the infidel, too. ${ }^{45}$ And finally, as part of a theory of virtue, it could be expressed as a subjective right or faculty that could now be understood as part of a universal theory of commutative justice: it would express social relations in inter-subjective terms as rightful forms of the exercise of dominium all over the world.

\section{A universal system of private exchanges}

Through the discussion of dominium, Vitoria, Soto, and the subsequent Salamanca scholars grounded an extensive right for human beings to appropriate, use, transfer, or abandon things in accordance with their choice. Such a right belonged only to rational (human) beings, but it belonged to all of them. The Spanish Dominicans followed what had been the official Church line since the Council of Constance (1414-8), according to which neither sin nor infidelity took away dominium; that was why Christians might lawfully engage in trade with pagans and the

43 This theory is laid out in quite a complicated and partly contradictory way in the early lecture, Vitoria, 'On Civil Power,' supra note 38, §5-8 (9-17).

44 See especially Vitoria's commentary on the secunda secundae in Comentarios, supra note 32, 57.1 (1-6) (in which Vitoria adopts the Thomistic definition of 'ius' as the object of 'iustitia'), 58.1 (20-1) (where the definition of 'justice' is given in terms of giving everyone his due), and the discussion of dominium in terms of commutative justice and as a property all humans have; ibid, 62.4 at ns $8-17$ (67-74). See further Brett, Liberty, Right and Nature, supra note 9 at 4-137. For Soto's position regarding the foundation of dominium in liberty and the use of the 'light of reason,' see Soto, $D e$ iustitia, supra note 9, 4.1.1 (280a-b), 4.1.2 (283-5).

45 See ibid, $4.2 .2(290 \mathrm{a}-\mathrm{b})$. 
rights of ownership of the latter might be enforced even against the Christians. $^{46}$

But the problem was larger than questions about Indian rights. As Vitoria was teaching, the gold and silver that were being imported to Seville from the Indies and the export opportunities for manufactured goods to the Americas as well as the financing related to those opportunities began to create a network of global relations that would transform the cultural and economic milieu all over Europe beyond recognition. Commercial operators (including the Crown itself) were engaged in new types of transaction - long-distance trade, monopolies, and pricespeculation - in a moral-legal gray zone that theologians could not ignore. What to think of the drive to profits based on large-scale exchanges of private property? ${ }^{47}$

For Aquinas, the move from common to private property originally had a utilitarian basis: "[E]veryone is more diligent in procuring something for himself than something which is to belong to all or many'; 'human affairs are conducted in a more orderly manner if each man is responsible for the care of something which is his own'; and 'a more peaceful state of things is preserved for mankind if each is contented with his own.' ${ }^{48}$ The Salamanca scholars followed this direction; their relatively relaxed discussion of profit making in commercial operations and usury presupposes the justice of such activities as long as they can be understood as motivated by concern for the livelihood of one's family or the good of the commonwealth. ${ }^{49}$ True, many Christians were critical of private property, pointing to biblical passages such Jesus's statement that the rich man will have difficulty entering Paradise (Luke 18.25). But most of them followed Aquinas and accepted private property as a pragmatic 'addition' to natural law (instead of a sinful deviation from it) and valid overall as ius gentium, a position that was consolidated within the Church at the latest during the Franciscan poverty controversy. ${ }^{50}$

46 'Infideles possunt habere tale dominium supra christianos, id est stando in jure naturali, no perdit infidelis dominium suum propter infidelitatem, sed talibus tenentur christiani obedire' in Vitoria, Comentarios, supra note $32,62.10 \S 1$ (200).

47 For a rapid overview of the authors and the principal themes discussed here, see e.g., Dominec Melé, 'Early Business Ethics in Spain: The Salamanca School (1526-1614)' (1999) 22:3 Journal of Business Ethics 175 at 177-84.

48 Aquinas, Political Writings, ed and translated by RW Dyson (Cambridge, UK: Cambridge University Press, 2002) 66.2 at resp (208).

49 As especially stressed in Joseph A Schumpeter, Histoire de l'analyse économique, $\mathrm{t}$ 1, translated by J-C Casanova (Paris: Gallimard, 1983) at 141-57.

50 Aquinas, supra note 48, 66.2 (208); Janet Coleman, 'Property and Poverty' in JH Burns, ed, The Cambridge History of Medieval Political Thought c 350-c 1450 (Cambridge, UK: Cambridge University Press, 1988) at 621-5. On the Franciscan poverty controversy, see ibid at 631-48; Brett, Liberty, Right and Nature, supra note 9 at 13-20. 
Soto, for example, begins his discussion of private ownership by attacking what we might call Plato's communist utopia in the Timaeus and the Republic. The effective use of resources, he argues, requires that each be given his own property to use and administer. Moreover, only such a division ensures the right distribution of burdens among the members of the community. In Paradise, there may be sufficient fruit for everyone. But since the expulsion, humans have had to work in order to earn their living. In such conditions, maintaining common property would lead to some working excessively while others would simply lie back to enjoy the fruits of others' labour. The peace, tranquillity, and friendship sought after by the philosophers would inevitably be thwarted. ${ }^{51}$ Moreover, Soto points out following Aristotle, under conditions of common property it would be impossible to cultivate the virtues of hospitality and liberality - without private ownership neither of them would serve any point. ${ }^{52}$

Everything Vitoria and Soto wrote about the laws of contract and inheritance, prices, money, and commerce at home and with foreign countries as well as about the objectives and limits of public power presumes not only the existence but the beneficial nature of private property and the transactions connected with it. ${ }^{53}$ Such transactions had been discussed in Roman (civil) law, but no systemic view of them had emerged until the scholastics brought them under the title of commutative justice "intimately bound with the sacrament of confession.' ${ }^{54}$ For Vitoria and Soto were keenly aware that the accumulation of wealth

51 Soto, De iustitia, supra note 9, 4.3.1 (296a-7a); 'Hac ergo delira communitate praetermissa ... . demonstrandum [est] quam sit congruens naturae corruptae possessionum divisio ... nempe ex humana negligentia et ex cupiditate; ibid at 296b. See also Alejandro A Chafuen, Faith and Liberty: The Economic Thought of the Late Scholastics (Lanham, MD: Lexington Books, 2003) at 33-4.

52 'Qui enim proprium non habet, liberalis esse non potest et qui omnia possidet, alienae liberitatis non eget'; Soto, De iustitia, supra note 9, 4.3 .1 (297b). See also Aristotle, The Politics, translated by AT Sinclair, revised by TJ Saunders (Harmondsworth, UK: Penguin Books, 1981) at 1263a (115).

53 In this, they departed significantly from the views of medieval writers, who were usually dubious about economic activity and accepted it only to the extent that it was directed towards satisfying needs or caring for offspring; see, e.g., Antonio García García \& Bernardo Alonso Rodriquez, 'El pensamiento económico y el mundo del derecho hasta el siglo XVI' in Gómez Camacho \& Ricardo Robledo, eds, El pensamiento económico en la escuela de Salamanca (Salamanca, Spain: Ediciones Universidad de Salamanca, 1998) 65 at 66-75 [García García \& Rodriquez] [Camacho \& Robledo]. Diana Wood observes that it was the Church that put a brake on economic activity; for 'to be socially ambitious, to want to be upwardly mobile, was a sin'; Diana Wood, Medieval Economic Thought (Cambridge, UK: Cambridge University Press, 2002) at 3, $2-5$.

54 Thomas Duve, 'La teoria de la restitución en Domingo de Soto: Su significación para la historia del derecho privado moderno' in Juan Cruz Cruz, ed, La ley natural como 
could easily cross the threshold of the sin of avarice. In their commentaries on Aquinas, they thus balance their utilitarianism with their concern for the souls of the merchants by developing an extremely detailed casuistry of different types and practices of contracts, loans, forms of exchange and insurance as well as other economic transactions. ${ }^{55}$

Vitoria took up the law and ethics of commerce - that is to say, the practice of buying cheap and selling dear - in his commentary to questions 77 and 78 of the Summa in his course in $1535-6 .{ }^{56} \mathrm{He}$ did this by following the Parisian nominalists and the greatest Dominican of the preceding period, Tommaso de Vio, Cardinal Cajetan (1468-1524)..$^{57}$ Following Aristotle, Vitoria distinguishes between two types of ars mercatorum, 'natural' exchanges, the purpose of which was to see to the good of the household ('ad usus necessarios hominum') and those 'artificial' operations whose point was to produce profit ('ad lucrum'). The former were just and lawful but the latter, especially if practised systematically, involved great danger ('est valde periculosum') for the soul. ${ }^{58}$ Profit making for private gain would constitute the mortal sin of avarice - it was contrary to the virtues of liberality and justice. It distorted the relationship of equality between the buyer and the seller that it was the point of commutative justice to uphold and caused injury to others. Say you buy a horse that you do not need only to sell it at a higher price. In that case, you cause injury to the original seller, who could have received a higher price by dealing directly with the person to whom you sold it. And you injure that third person because, in interacting directly with the original seller, he might have made a better bargain. ${ }^{59}$

fundamento moral y jurídico en Domingo de Soto (Pamplona: Ediciones Universidad de Navarra, 2007) 181 at 190, 187-90.

55 Belda Plans, La escuela de Salamanca, supra note 9 at 926; José Barrientos García, 'El pensamiento económico en la perspectiva filosofico-teologica' in Camacho \& Robledo, supra note 53, 93 at 94-5 [Barrientos García, 'El pensamiento económico']. To give a sense of the detailed nature of the result, it might be noted that Vitoria's discussion of the question of 'whether it is allowed to receive for loan something else than money in exchange' is divided into seventy-five paragraphs that discuss fifty-one 'doubtful cases,' many of them developed in several 'corollaries,' all of which are taken from the modern Latin edition and total altogether sixty-eight pages in Vitoria, Comentarios, supra note 32, 68.2 (167-235).

56 Ibid (106-240).

57 For Vitoria's sources, see José Barrientos García, Un siglo de moral economica en Salamanca (1526-1629): Francisco de Vitoria y Domingo de Soto (Salamanca, Spain: Ediciones de Universidad de Salamanca 1985) at 31-6 [Barrientos García, Un siglo de moral economica].

58 Vitoria, Comentarios, supra note 32, $77.4 \S 2$ (146).

59 'Dicunt ergo omnes doctores supra allegati quod tales peccant mortaliter'; ibid, $77.4 \S 4$ (149). 
Like Aquinas, however, Vitoria assumed that the justice of profit making depended ultimately on its purpose, and he did not wish to discourage activities that were beneficial to the commonwealth. What was needed was to learn to discriminate among situations. The profit due to the merchant could be justified above all by the change that had been made in the commodity by transporting it from the place where it was bought to the place where it would be sold. As the goods were sold in a location where they were scarce or perhaps not available at all, the merchant was performing a socially useful service for which he could be justly rewarded ("hoc est necessarium ad bonum et ad provisionem reipublicae $).{ }^{60}$ If profit enabled commerce where it would otherwise be lacking, or if it contributed to the good of the community in other ways, it was just. The focus on the subjective motivations of the seller was, of course, a highly fluid standard. For example, Vitoria argued that, if a necessary item - such as wheat, for example - was scarce, but the seller waited until its price rose, then his action would constitute, depending on the gravity of the matter, either venial or mortal $\sin { }^{61}$ On the other hand, however, Vitoria also took up the classical example of the merchant who has arrived in a port and begins to sell the grain he has on board. He knows that more ships are underway, which means that the price of grain will soon sink. Does he have the duty to disclose what he knows? Vitoria's accepting that keeping silent in this situation is not a sin shows that he was prepared to accept attitudes in commerce which he would not have accepted between individuals otherwise. Like all the scholastics, he was, of course, adamant that fraud or coercion is always illegitimate, including keeping silent about a defect in a product that one knows about. But he did accept that at least some special rules applied in commercial relations. ${ }^{62}$

An especially significant extension of the theory of dominium was the subjective (but non-arbitrary) theory of the 'just price' that lies at the heart of the Salamancans' views on commerce. ${ }^{63}$ Drawing on the nominalist

60 Ibid, $77.4 \S 2$ (147).

$61 \mathrm{Ibid}, 77.4 \S 1-2(141-7)$. This is, in fact, a very lax standard - for mortal sin is involved only if profit is actually intended to harm others. If it is motivated only by greed, the sin is venial - a sign that Vitoria and the humanists generally were shifting attention from the state of mind of the economic operators to the actual injury possibly caused by their operations; see García García \& Rodriquez, supra note 53 at 82.

62 Barrientos García, Un siglo de moral economica, supra note 57 at 65-6.

63 The just price is not only an economic category in Vitoria and Soto but is, above all, a measure of the requirement of commutative justice in the moral-legal order. It puts into practice the need to ensure the equality and reciprocity of exchanges; see Juan Antonio Widow, 'Economic Teachings of Spanish Scholastics' in Kevin White, ed, Hispanic Philosophy in the Age of Discovery (Washington, DC: Catholic University of America Press, 1997) 130 at 135-6. Vitoria and Soto were not simply adopting a 
theologian Duns Scotus (but also Roman law), Vitoria accepted that the goods on the market had no essential or natural value. He was familiar with the paradox under which water, though normally of no value, may be sometimes regarded as more valuable than gold. But how, then, if different people value things differently, could a just exchange be carried out? To this all the Salamancans would respond that the just price is relative to how a thing is valued in the place and at the time when it is sold ('ex communi hominum aestimatione vel condicto'). ${ }^{64}$ 'Common estimation,' again, was a function of many things, including the product's relative abundance or scarcity (to which later Salamancans such as, above all, the canon lawyer Azpilcueta would add the amount of money available). In other words, though price-formation was a subjective process, this did not mean that there was no just price. It was simply that what the just price was depended on local circumstances. ${ }^{65}$ In this way, Vitoria began to shift his focus away from the subjective motives of the buyer and seller so as to take account of the larger commercial context in which the justice of the exchange should be assessed. To what extent did this mean that the moral-legal standard was set by business practices? To set limits to this flexibility, Vitoria and the other Salamancans rejected monopolistic practices and considered situations where the 'common estimation' would not function properly as a standard because there were either too few buyers or too few sellers; they held that, inasmuch as such a situation arose with respect to necessary items, the king must fix a 'legal price' for the product. ${ }^{66}$ But the price of non-necessities, items that later analysts would label 'luxuries,' could be freely agreed - here 'volenti non fit injuria.' ${ }^{\prime} 7$

A particular point of concern was the novel forms of banking and credit that facilitated long-distance trading and helped to sustain the government's engagement in its unending wars. The traditional perspective on this was provided by the prohibition of usury, extensively discussed by the Salamancans with reference to question 78 of the second part of the second part (Secunda Secundae) of the Summa. The prohibition of usury had many justifications, one of which was that taking interest for a money loan was prohibited because it was unnatural: money was sterile

nominalist position. Although the price of a commodity was determined subjectively, that determination reflected an objective assessment of the situation in the market.

64 Vitoria, Comentarios, supra note 32, $77.1 \S 2$ (117-8).

65 Deckers, supra note 42 at 247-8; Chafuen, supra note 51 at 82-3.

66 See also Ricardo F Crespo, 'La posibilidad y justicia del intercambio: De Aristoteles a Marx, pasando por Tómas de Aquino y Francisco de Vitoria' in Juan Cruz Cruz, ed, Ley y Dominio en Francisco de Vitoria (Pamplona, Spain: Ediciones Universidad de Navarra, 2008) 267 at 273-5.

67 Vitoria, Comentarios, supra note 32, 77.4 (120); Barriento García, Un siglo de moral economica, supra note 57 at $47-8$. 
and making it produce was contrary to natural law. ${ }^{68}$ From the twelfth century on, however, commercial practices had developed with the purpose of circumventing the prohibition, for example, by breaking the loan into two or three separate acts of exchange. The justice of this and other practices had been intensively discussed among the Parisian doctors throughout the fourteenth and fifteenth centuries, whose writings, as well as those of the Tübingen theologian Konrad Summenhart (c. 1450-1502) and Cajetan's De Cambiis (1519) constituted a major inspiration for Vitoria and his followers.

Opening trade routes to the Americas had led to the introduction of huge quantities of gold and silver into the European and Asian markets. The principal European marketplaces - Seville and Medina del Campo in Spain, together with Antwerp, Lyon, and Venice - became buzzing centres of commercial activity in which merchants from all over Europe - and also from Spain - engaged in routine speculation for profit and accumulation. The new commercial culture sat uneasily with the traditional image of the virtuous life. What should one think of taking interest for exchanges of money that enabled efficient trading in successive fairs in different countries? The traditional prohibition of usury had been motivated by lending for consumption to private individuals or families. But what about lending for productive purposes - for example, for chartering ships to the Indies or for providing capital for joint commercial ventures in the expectation of profit? ${ }^{29}$ The Spanish cambistas operating in Antwerp were actually so worried about such practices that, in 1530, they sent a report to the University of Paris requesting an assessment of whether usury was involved. That the response from Paris condemned such exchanges did not make them disappear, however. Vitoria, too, was consulted in this connection but confessed only to his bewilderment by the complexity of the problem and made no important contribution to its clarification..$^{70}$ His discussion of the matter four years later in his lectures on the Summa is likely to have been inspired by the consultation and by the transformation of the world of international commerce to which it related.

The Salamancans did not see money as just a sign or an instrument of exchange. It had value in itself so that it could also be understood to accumulate for investment purposes and be exchanged for profit

68 Vitoria, Comentarios, supra note $32,78.1 \S 1,3(153-4,155)$.

69 For a discussion of the novel practices, see Abelardo del Vigo Gutierrez, Cambistas, Mercaderes y banqueros en el siglo de oro español (Madrid: Biblioteca de autores christianos, 1997), 211-35.

70 See Marjorie Grice-Hutchinson, The School of Salamanca: Readings in Spanish Monetary Theory 1544-1605 (Oxford: Clarendon Press, 1952) at 38-9 [Grice-Hutchinson, School of Salamanca]; and for the consultation, Appendix 1, ibid at 120-6. 
(interest). Vitoria's extensive treatment of usury opens with an apparently unconditional prohibition of interest-taking in lending. Nevertheless, in the course of his discussion, he adds several qualifications to that prohibition and ends up positively endorsing the operations of the cambistas, or professional money exchangers, inasmuch as they exchanged currencies but also provided credit and letters of exchange that enabled merchants to move among fairs in Europe without having to carry large quantities of money with them. ${ }^{71}$ Vitoria's perspective on the emerging financial network, however, was still provided by focusing on the motivations of individual cambistas and bankers. This would soon be overcome by the systemic nature of the operations.

It was crucial for the expansion of commerce that merchants were able to make international payments rapidly and flexibly. This took place through the instrument of the letter of exchange (cambio de litteras) issued at one fair to be cashed at another fair a few months later. In long-term business contacts, it was practical for traders to provide such letters to each other whereby they could credit their payments at later fairs against what they had sold at earlier ones. But they would also use these as independent instruments for making payments to third parties that would ultimately be guaranteed by the banks and other professional credit providers by whom the original letter had been signed and issued. ${ }^{72}$ In the course of the sixteenth century, the system of letters of exchange (and re-exchange) and various forms of deposit and ex gratia payment intended to circumvent the prohibition of usury developed into a massive system of operations within which, according to the assessment of Vitoria's Salamanca colleague, the canon lawyer Azpilcueta, the profit for the cambista would fluctuate somewhere between 5 and 12 per cent. To manage the expanding financial and monetary system, the number of cambistas and bankers also began to exceed the number of regular merchants at trade fairs, which turned in the sixteenth century into accounting conferences where the cambistas cleared their clients' payments by reciprocal entries in their accounting books so that 'the

71 Vitoria, Comentarios, supra note $32,78.2 \S 61-75(223-5)$. The cambista provides a service that is useful for the community and for which it is lawful to require a benefit in return. However, unlike Cajetan, Vitoria extends this right beyond the practices of professional bankers to the transactions that merchants do on a permanent basis and that have the objective of facilitating long-distance trade (but not between nearby cities), ibid, §66, 69 (227-8, 229).

72 For good descriptions of these practices, see, e.g., García García \& Rodriquez, supra note 53, 65 at 81-90; Jean Favier, Gold and Spices: The Rise of Commerce in the Middle Ages, translated by Caroline Higgitt (New York: Holmes \& Meier, 1998) at 223-6; and, of course, Fernand Braudel, Civilization and Capitalism: 15th-18th Century, vol 2, translated by Siân Reynolds, (Berkeley, CA: University of California Press, 1992) at $138-54$. 
fairs gradually became clearing-houses for the whole of Western Europe.' ${ }^{73}$

Vitoria and Soto witnessed the development of this financial system, together with the unprecedented rise of prices in Spain as a result of the importation of gold and silver from the Indies. This led first Azpilcueta and then the rest of the Salamancans to subscribe to the quantity theory of money (that the value of money is relative to its quantity on the market) that wholly departed from assessing lending activities from the perspective of individual cases of conscience. ${ }^{74}$ As Soto explains,

The more plentiful money is in Medina the more unfavourable are the terms of exchange and the higher the price that must be paid by whoever wishes to send money from Spain to Flanders, since the demand for money is smaller in Spain than in Flanders. And the scarcer money is in Medina the less he need pay there, because more people want money in Medina than are sending it to Flanders. ${ }^{75}$

Four-hundred dinars in Spain might thus have the value of threehundred in Flanders without anybody along the way making themselves guilty of the sin of usury. Moreover, in complicated international exchanges that involved several parties and a number of currency valuations and exchanges, it was difficult to determine the equilibrium or reciprocity required by commutative justice. One flexible basis for accepting interest was that it could be assumed that lending caused some damage to the lender and that interest could be understood as compensation (damnum emergens) or even, in some instances, for unattained profit (lucrum cessans). ${ }^{76}$ There was, however, rarely any actual measurement of such losses and even the theologians tended to accept rates that were in effect in prevailing business practices under the principle of the 'common estimation.' 77

The Salamanca writers thus accepted that price fluctuations among the fairs may be justly taken into account in determining the value of money to be exchanged or, indeed, of a letter of exchange issued in

73 Grice-Hutchinson, School of Salamanca, supra note 70 at 11.

74 For a clear statement of the 'quantity theory' through a comparison of price levels and the amounts of money available in France and Spain, see Martin de Azpilcueta, 'Commentary on the Resolution of Money' in Stephen J Grabill, ed, Sourcebook in Late-Scholastic Monetary Theory: The Contributions of Martin de Azpilcueta, Luis de Molina, SJ, and Juan de Mariana, SJ (Lanham, VA: Lexington, 2007) at para 21 (50-1) [Azpilcueta, 'Commentary'] [Grabill].

75 Soto, De iustitia, supra note 9, 6.12 .2 (595a-b); and translation in Marjorie GriceHutchinson, Early Economic Thought in Spain 1177-1740 (London: Allen \& Unwin, 1978) at 103 [Grice-Hutchinson, Early Economic Thought].

76 Vitoria, Commentarios, supra note 32, 78.2 (167-8); see also Soto, De iustitia, supra note 9, 6.1.1, 6.1 .3 (508a-514b, 521b-525b).

77 Vigo Gutierrez, supra note 69 at $304-9$. 
one place to be cashed in another. In fact, Soto seems to have been 'among the first scholastic writers to describe and approve of the credit creation of the banks.' 78 The matter, Azpilcueta and others began to argue, is no different from profits emerging from exchanges of regular commodities. In cases where the profit is not unreasonable (i.e., there is no laesio enormis), no fraud or coercion is involved, and prices are not manipulated to the detriment of the community, then it is lawful. ${ }^{79}$ If Vitoria (and Azpilcueta) were still dubious about the justice of all this and persisted in conceptualizing the exchanger's profit as a 'fee' for services (of counting, depositing, carrying the risk, etc.), by the end of the century, the Jesuit Luis de Molina (1535-1600) could already report, that in the opinion of the majority of the doctors, exchanges that gave a profit based on the divergence of the currencies were perfectly legitimate, even if they, as he correctly put it, 'demand little work, scarce effort, and no risk.' ${ }^{80}$

Molina's views emerged from what was already a 'systemic' view of money and economic exchanges. The fact was that demand and supply were now being organized on an international scale by bankers in Italy, Germany, Flanders, and England so that, as a result, princes started to become, for the first time, even theoretically unable to control the price levels of goods in their territories. As the network of international exchanges widened, it began to operate increasingly with different types of paper money, the value of which was determined by the credit policies of international banks and other financial institutions. As these same institutions also lent the funds needed by Charles $\mathrm{v}$ to carry out his incessant wars, he was compelled to direct whatever domestic sources of revenue he could muster to the payment of his debts, thus tying his hands in regard to domestic policy as well. There was nothing new in this. When Charles's grandfather Maximilian I died in 1519, his debt to the Fuggers and the Welsers of Germany amounted to eighteen times his annual income - and late in his regime, Charles's son Philip II was compelled to spend two thirds of his income on interest for his debts. ${ }^{81}$

78 Grice-Hutchinson, Early Economic Thought, supra note 75 at 104. For Azpilcueta's agonizing acceptance of profits from exchange services at successive fairs ('it seems absurd to condemn so many merchants who carry this out and by [condemning them] to hurt everyone'), see Azpilcueta, 'Commentary,' supra note 74 at paras 72, 68-76 (83, 82-6).

79 García García \& Rodriguez, supra note 53 at 70; Wood, supra note 53 at 148-9.

80 Luis de Molina, 'Treatise on Money' in Grabill, supra note 74, 139 at 188.

81 MN Pearson, 'Merchants and States' in James D Tracy, ed, The Political Economy of Merchant Empires (Cambridge UK: Cambridge University Press 1991) 41 at 80; Thomas A Brady, 'The Rise of Merchant Empires, 1400-1700: A European Counterpoint'; ibid, 117 at 145-6. The financers were happy to finance these risky 
Vitoria and Soto assumed that these economic exchanges were based on a universal right of dominium applicable all over the world. The right of dominium would provide, for example, the basis on which Catholic merchants from Spain could engage in mutually profitable transactions with Islamic or Jewish traders (as they had, of course, done for centuries), travel to Protestant markets in Germany and the Netherlands, or trade and exchange goods with the inhabitants of the New World. The most famous sketch of this worldwide system of dominium is contained in Vitoria's discussion of the right of the Spaniards to travel and trade in the Indies (ius pergrinandi $\mathcal{E}$ ius negotiandi), which is based on the naturalist theory of human sociability together with the principle of dominium that was articulated as ius gentium. Vitoria portrays trade and commerce as part of the 'natural partnership and communication' among humans. From the beginning of time, 'everyone was allowed to visit and travel through any land he wished [and t] his right was clearly not taken away by the division of property (divisio rerum). ${ }^{82}$ It was a practical consequence of this that all nations were to show hospitality to strangers and everybody had the right to 'all things that were not prohibited or to the harm or detriment of others. ${ }^{83}$

This, again, meant that

Spaniards may lawfully trade among the barbarians, so long as they do no harm to their homeland. In other words, they may import the commodities which they lack, and export the gold, silver, or other things which they have in abundance; and their princes cannot prevent their subjects from trading with the Spaniards, nor can the princes of Spain prohibit commerce with the barbarians ... [T] he law of nations (ius gentium) is clearly that travellers may carry on trade as long as they do no harm to the citizens ... [A] ny human enactment (lex) which prohibited such trade would indubitably be unreasonable. ${ }^{84}$

And to make clear that he is not only discussing some special (colonial) relationship between the Spanish and the Indians, Vitoria adds that these principles are the same as those that apply between Christian commonwealths. For the Spanish or the French kings to intervene in the travel of private traders would be 'unjust ... and contrary to Christian charity.' ${ }^{85}$

All of this begins to reveal an international system of commerce, based on the free use of their dominium by private merchants and bankers,

ventures because it brought them silver that they could invest in further mercantile activities or convert into gold for excellent profit; see Giovanni Arrighi, The Long Twentieth Century: Money, Power and the Origins of Our Times, new and updated ed (London: Verso, 2010) at 123-9.

82 Vitoria, 'On the American Indians,' supra note 13, $3.1 \S 2$ (278).

83 Ibid.

84 Ibid, 3.1 § $3(279-80)$.

85 Ibid, $3.1 \S 3$ (280). 
which princes were not entitled to impede. ${ }^{86}$ The extent of dominium was wide, covering use and non-use, trading and exchange as well as throwing away of the object. The prince was not entitled to intervene in his subjects' use of private property 'unless this is necessary for the defence and government of the nation.' ${ }^{87}$ Nor could he limit, without just cause, hunting, fishing, or collecting firewood from the forest. The right to use all this flows from the original natural law provision that humans may use everything that is necessary for their preservation. ${ }^{88}$ If the ruler abused his authority, he committed a crime and had the obligation to restore the property taken. ${ }^{89}$ To expropriate subjects' property arbitrarily - something that had been a persistent reality in fifteenth century Spain - would turn the prince into a tyrant and trigger the right of resistance of the commonwealth. Some, such as Mariana, wrote with particular vehemence against the practice of debasing the value of coinage, which he held as equal to theft by the king (Philip II) of his subjects' property. ${ }^{90}$ Expropriation was possible only when the prince had a permissible causa; that is to say, only so far as needed by the commonwealth '[b] eyond that, man must not only have his own rights as an individual, but he must also have their exercise in his own control: in other words, he must be sui iuris, have dominium of himself or his liberty.' ${ }^{91}$

The theory of dominium as the sphere of freedom - especially, economic freedom - belonging to human beings by ius gentium now opened a wholly new way of speaking of universal authority beyond dubious claims about papal or imperial power. Any statement under the via antiqua that laid out duties connected with an office or rule could now be redescribed as a statement about what (some) human beings had an entitlement to. 'And the important thing about the sixteenth-century Spanish theologians and lawyers was that they did frame those issues in terms of the individual. ${ }^{92}$ The universal structure of private rights that emerges from Vitoria and Soto spoke to popular views about the electoral basis of Spanish monarchy and bound the ruler - at least, in principle - to the original authorization to rule in

86 Barrientos García, 'El pensamiento económico,' supra note 55 at 120.

87 '... nisi quando eidem reipublicae tuendae $\mathcal{E} \sigma$ administrandae necesse fuerint'; Soto, De iustitia, supra note 9, 4.4.1 (301a).

88 Vitoria, Comentarios, supra note 32, $62.1 \S 13$ (72-3); see also Deckers, supra note 42 at $210-1$.

89 Soto, De iustitia, supra note 9, 5.3 .5 (430a).

90 Juan de Mariana, 'A Treatise on the Alteration of Money' in Grabill, supra note 74, ch 3 at 260.

91 Brett, Liberty, Right and Nature, supra note 9 at 159.

92 Annabel Brett, 'The Development of the Idea of Citizens' Rights' in Quentin Skinner \& Bo Stråth, eds, States and Citizens: History, Theory, Prospects (Cambridge, UK: Cambridge University Press, 2003) 97 at 100. 
the common good, understood as the free operation of dominium-rights. ${ }^{93}$ It established a universal field of economic liberty that could be invoked against all holders of public power. Wherever authority was being exercised, it could now be assessed in light of universal rights of property, self-defence, travel, trade, taking of possession of ownerless things, and so on. This was an inevitable consequence of the fact that Vitoria and Soto dealt with dominium in the context of commutative and not distributive justice; that is, relationships among subjects themselves, excluding ideas about the intervention of public power. Chafuen summarizes the resulting economic views of the Spanish scholastics as follows:

Late-scholastic theory analyzed profits, wages and rent as matters of commutative justice and applied rules similar to those used to analyze the prices of goods. The Schoolmen determined that wages, profits and rents are not for the government to decide. Since they are beyond the pale of distributive justice, they should be determined through common estimation of the market. ${ }^{94}$

The world was an empire, but an 'empire of private rights.'

But this is, still, not yet all. For the universalization of private dominiumrights by ius gentium was accompanied by rules on their enforcement under the theory of just war. In addition to justifying warfare by Christians - by no means a small accomplishment - this theory did two things. First, it defined the political commonwealth as the sovereign state. In the second relectio on the Indians, which moves from the question of Spanish title to the issue of enforcement by war, Vitoria followed tradition by asking who was entitled to wage war and gave an equally traditional response - only the prince might do that. And this could only be a prince who was the head of a 'perfect community', one that was 'complete in self: that is which is not part of another commonwealth. ${ }^{95}$ This also included, for Vitoria, the commonwealths that were part of the empire, because they were de facto self-sufficient. Far from advocating any idea of an international community, we see Vitoria, here, declaring the Holy Roman Empire - of which his king was the head - legally extinct. Only states might engage in war, and statehood was a matter of the factual self-sufficiency of an entity.

Second, the theory of just war then came to underwrite the double structure of dominium and ius gentium discussed earlier. What are the conditions of just war? Religious differences were not, as Vitoria takes pains to point out, nor 'enlargement of empire or personal glory or convenience.' The only just cause for war was 'when harm ha[d] been inflicted.' 'War

93 Giovanni Ambrosetti, Il diritto naturale della riforma catolica (Milan: Giuffre, 1951) at 60-1.

94 Chafuen, supra note 51 at 102-3 [footnote omitted].

95 This theory is laid out in a quite complicated and partly contradictory way in the early lecture, 'On the Law of War'; Vitoria, 'Law of War,' supra note 31 at 301. 
[was] for the avenging of injuries and the admonishment of enemies. ${ }^{{ }^{96}}$ An injury was a violation of the right of dominium. This covered, on the one hand, the system of rule in the state - for 'the defence and preservation of the commonwealth is the purpose of war' - but also of avenging injuries done to private individuals or their property. This covered, naturally, the injury done to subjects but also injustice (iniuria) to other men. ${ }^{97}$ In his early relectio on cannibalism, Vitoria had already pointed out that war could be waged on the Indians in order to protect the innocent. In the lecture on war, he extended the powers of the prince to punish the wrongdoer for the damage he has done to include injury done by individuals wherever they might be - a kind of universal power to protect dominium:

[T] he prince has the authority not only over his own people but also over foreigners to force them to abstain from harming others; this is his right by the law of nations [i.e. ius gentium] and the authority of the whole world. ${ }^{98}$

War, then, was not something for enforcing a substantive view of the good life or for Christian evangelization. It was allowed only so as to enforce the public-law jurisdiction of the sovereign prince, which might have been violated by the enemy, or when the private dominium that individuals had over both their freedom and their property had been violated. And this right of just war was applicable everywhere.

VI Suárez to Grotius

It fell, then, to the Jesuit Francisco Suárez to bring these arguments to a conclusion in his massive De legibus (1613). ${ }^{99}$ Like Vitoria, Suárez saw dominium as based not on natural but on positive law; it was something established by humans for their own utility. Natural law had been enacted by God and provided for freedom, common ownership, and peace. It was not subject to change. ${ }^{100}$ But its content was often derived only 'negatively' from the absence of an express prohibition. In that space of non-prohibition, the subjective freedom of humans - their dominium - operated as their legal right to create commonwealths as well as to divide and exchange property. Natural law, Suárez wrote, left

96 Ibid at 303.

97 Francisco de Vitoria, 'On Dietary Laws' in Vitoria, Political Writings, supra note 13, 205 at 225 .

98 Vitoria, 'Law of War,' supra note 31 at 305.

99 Francisco Suárez, 'On Law and God the Lawgiver (De legibus, ac Deo legislatore)' in Francisco Suárez, Selections from Three Works, vol 2, translated by G Williams (Oxford: Oxford University Press, 1944).

100 Ibid, $2.15 \S 14$ (276), $3.2 \S 3$ (373-374). 
'the matter to the management of men, such management to be in accordance with reason.' ${ }^{101}$

This created a difficulty, however. If private property was based on human law, did natural law then have nothing to say about stealing? To strengthen the (subjective) dominium-right, Suárez referred back to the distinction he had made at the outset of his treatise between ius as objective law and ius as subjective right; that is, as a 'certain moral power which every man has either over his own property or with respect to that which is due to him.' ${ }^{102}$ When natural law provides for this kind of subjective right ('ius dominativum'), he explains, it does this always as a positive precept from which no deviation is allowed. In the original state, everyone had dominium in common with others. After the intervention of divisio rerum, that positive, non-derogable right now attached to private property so that stealing became an evil, subject to punishment, just as taking from the common stock would earlier have been. ${ }^{103}$ Even if the institution of private property was purely human, in other words, once it was created, it was protected by natural law. This was also a command of faith. Already Soto had made the point that to deny private property was to engage in heresy. Suárez would agree but would provide a better explanation for why this was so: not because of utility but because of the nature of subjective ius. None of this is to say that Suárez would turn out to have the preferences of the modern liberal. In fact, his view of the sphere of liberty of the individual in society was very limited. But the authoritarian basis for his view of the government of the commonwealth came from a liberal argument from individual liberty: 'for the very reason that man is lord of his own liberty, it is possible for him to sell or alienate the same.' ${ }^{104}$

But although Suárez took great trouble to distinguish between natural law on the one hand, and ius gentium as positive customary law on the other, he still did not hold the two as completely distinct. The relationship between the two was one between that which was intrinsically necessary and that which contributed to the attainment of the necessary in the real conditions of the world. Suárez gives two examples: diplomatic and commercial exchanges. Peace is dictated by natural law and the function of the ambassador was to contribute to peace. However, this did not make diplomacy part of natural law. Other means might lead to peace as well; hence its nature as ius gentium and not as natural law. It was part of the way humans had come to seek the good of their communities. The same argument applied to international commerce. Trade was by no means intrinsically necessary. But it

101 Ibid, $2.14 \S 6(270)$.

102 Ibid, $1.2 \S 5(30)$.

103 Ibid, $2.14 \S 13$ and 16-17 (275-7, 278-9).

104 Ibid, $2.14 \S 18$ (279); see also Reijo Wilenius, The Social and Political Theory of Francisco Suárez (Helsinki: Societas Philosophica Fennica, 1963) at 102-8. 
might be useful for the good of nations. Thus, like diplomatic relations, trade was established by the customary activities under the ius gentium and - like the subjective rights on which trade relations were based - once trade relations had been established, they were binding. As Suárez expressly says, "[I]t has been established by the ius gentium that commercial intercourse shall be free, and it would be a violation of that system of law if such intercourse were prohibited without reasonable cause.' 105

Like diplomacy, international commerce was a 'system' and like a violation of the former, a violation of the latter undermined the natural purposes for which that system had been set up and which were laid down in 'ius' in its first or 'objective' sense, as 'that which is in accordance with justice.' ${ }^{106}$ Of course, most of the rules of property or commerce dealt with relationships between individual right-holders and therefore had to be distinguished from the relations that pertained between princes and sovereigns. As Suárez explains in a famous passage,

A particular matter ... can be subject then to ius gentium in either one of two ways: first it is the law which all the various nations and people ought to observe in their relations with each other; secondly, on the ground that it is a body of laws which individual states or kingdoms observe within their borders, but which are called ius gentium because the said laws are similar [in each instance] and are commonly accepted..$^{107}$

This distinction between public international law as law among those who hold dominium in terms of jurisdiction over territory and the universal laws governing inter-individual relations of contract and ownership has, of course, become a key part of our understanding of two types of universal law. Even as private relationships are covered by the civil laws of the various countries, the general principles of those civil laws - including, above all, the freedom of commercial exchanges on the basis of private ownership - are still valid as ius gentium and enforceable through all those means that enable reaction to serious injuries to dominium irrespective of where they take place. To disrupt commercial relations, writes Suárez, is a violation of ius gentium that is punishable by war. ${ }^{108}$

105 Suárez, supra note 99, $2.19 \S 7$ (347).

106 Ibid.

107 Ibid, $2.19 \S 8$ (347).

108 Ibid, $2.19 \S 7$ (347); and on the relevant grounds of just (aggressive) war in the case of 'denial, without reasonable cause, of the common rights of nations, such as the right of transit over highways, trading in common \&c.,' see 'Disp XIII: On War,' ibid, section $4 \S$ 3 (817) (On The Three Theological Virtues: On Charity) as well as Josef Soder, Francisco Suárez und das Völkerrecht: Grundgedanken zu Staat, Recht und internationale Beziehungen (Frankfurt: Metzner, 1973) at 261. 
In twentieth-century debates about empire, focus is often on the first aspect of Suárez's twofold notion of ius gentium: imperialism as the predominance of a single sovereign, the hegemony of one state over others. It is this perspective, also, that has inspired students of Vitoria and the School of Salamanca to link their heritage to the formal expansion of Castilian rule over the American colonies. But what I would like to suggest, here, is that far more important than their writings on the Indies are the texts discussing dominium as the (subjective) right of property that is valid universally under the ius gentium and that can be, together with the derivative rights of travel and trade, enforced by just war.

From this perspective, the Spanish theologians and jurists of the sixteenth and seventeenth centuries appear not so much as reluctant advocates of a formal Spanish lordship over distant peoples but as articulators and ideologists of a global structure of horizontal relationships between holders of the subjective rights of dominium - a structure of human relationships that we have been accustomed to label 'capitalism.' In terms of the study of imperial relationships, the Spaniards appear distinctly as advocates less of 'formal empire' by advocating or supporting territorial annexations than of 'informal empire,' the control of resources through the exercise of private-law relationships of contract and property. Their significance is not limited to advocating imperial domination through the use of formal state power - a strategy that Europeans have resorted to only occasionally and, more often than not, with dire results for themselves. Instead, they appear as early articulators of the much more powerful and long-standing type of informal imperial domination that is achieved through a worldwide pattern of acquisition and exchange of private property by which - as the rulers of Castile would themselves learn quite rapidly - formal state policies are also controlled, enabled, or undermined, as befits the global market.

This was, of course, immediately seized on by the young advocate of the Dutch East India Company (VOC), Hugo Grotius, in his long defence, written in 1604-6, of the aggressive policy of the company to defeat Portuguese and Spanish efforts at maintaining a monopoly over trade in the East Indies. ${ }^{109}$ The debt owed by Grotius to the Spaniards - Vitoria, Soto, Vazquez, and others - is great and is often acknowledged, not least by Grotius himself. ${ }^{110} \mathrm{He}$ used them precisely to argue, against the Portuguese, for the freedom of navigation and of trade on the basis of a subjective right of dominium. Even if Grotius failed to mention Suárez in his main work De jure belli ac pacis which came out in

109 Hugo Grotius, Commentary on the Law of Prize and Booty (De jure praedae), ed and intro by MJ van Ittersum (Indianapolis, IN: Liberty Fund, 2006). [Grotius, Commentary]

110 See especially Alfred Dufour, 'Les 'Magni hispani' dans l'oeuvre de Grotius' in Grunert \& Seelmann, supra note 16,351 at $351-80$. 
1625, many of his formulations there, including his discussion of the objective and subjective meanings of ius, were 'undoubtedly' inspired by Suárez. ${ }^{11}$

Grotius fully grasped the implications of what the Spanish had been saying and deployed them in the service of the emerging Dutch commercial empire. Where the Iberians had weakened themselves by seizing vast stretches of territory in remote regions, the VOC was able to focus directly on profit making. This required refraining from territorial control but also internalizing protection costs through the company's setting up a military force of its own. The Dutch surpassed the Iberians because, as Arrighi has put it, the 'Iberian enterprise' 'was missing ... an obsession with profit and "economizing," rather than with crusade; a systematic avoidance of military involvements and territorial acquisition that had no direct or indirect justification in the "maximization of profit." ${ }_{112}$ This story is well known and much commented upon, so I will just limit myself to two points regarding the worldwide spread of dominium-rights and their enforcement by war. First, Grotius's search for a 'minimal natural law' as an uncontestable basis for universal law led him to highlight the desire for self-preservation as the legal foundation for the first two of his natural laws:

LAW I. It shall be permissible to defend [one's own] life and to shun that which threatens to prove injurious.

LAW II. It shall be permissible to acquire for oneself, and to retain, those things which are useful for life. ${ }^{113}$

These laws account for Grotius's reputation as the representative of an 'essentially modern theory of subjective natural rights.' ${ }^{114}$ It would be futile to review here, once again, the persistence with which Grotius privileged the subjective meaning of 'ius' as a right or a faculty that all human beings could 'have' as against the old, 'objective' meaning, under which it denoted a justice that merely 'was,' on the way from $D e$

111 Annabel Brett, 'Natural Right and Civil Community: The Civil Philosophy of Hugo Grotius' (2002) 45:1 Historical Journal 31 at 34 [Brett, 'Natural Right and Civil Community']. For a discussion of Grotius's debt to Suárez in respect of his famous 'etiamsi daremus' hypothesis, the case of there (per impossibilem) being 'no God,' see MB Crowe, 'The 'Impious Hypothesis': A Paradox in Hugo Grotius?' in Knud Haakonssen, ed, Grotius, Pufendorf and Modern Natural Law (Aldershot, UK: Ashgate, 1999) at 13-20 and references therein [Haakonssen, Modern Natural Law].

112 Arrighi, supra note 81 at 159.

113 These laws appear twice in the present translation of De jure praedae: first in Grotius, Commentary, supra note 109, ch 2 at 23, and Appendix A at 500.

114 Benjamin Straumann, 'Ancient Cesarian Lawyers in a State of Nature: Roman Tradition and Natural Rights in Hugo Grotius's De iure praedae' (2006) 34:3 Political Theory 328 at 330 . 
jure praedae to his mature treatise De jure belli ac pacis of 1625 . But it is useful, nevertheless, to highlight that Grotius linked his subjective rights expressly to a view of social relations governed by commutative (which he called 'expletive') justice instead of distributive justice which he relegated to the strictly non-legal field of human 'appetites' (instead of the legal 'faculties'). ${ }^{115}$ The universal validity of these rights was based simply on the universal character of the desire for self-preservation. They had a corollary, of course, which derived the social consequences of this (individualist) morality as follows:

LAW III. Let no one inflict injury upon his fellow.

LAW IV. Let no one seize possession of that which has been taken into the possession of another.

LAW v. Evil deeds must be corrected. ${ }^{116}$

Human beings not only were desirous of self-preservation, but also unlike animals - possessed reason. And reason taught them to forego immediate satisfaction of their needs and to join society in which their long-term interests would be best served. Private dominium and sociability were not in conflict but, rightly understood, complementary - just as subjective rights were complementary to the obligation of others to respect them. Grotius's famous concept of 'sociality,' which is supposed to be the 'mother' of natural law, is thus nothing else than the duty to respect the rights of others. ${ }^{117}$ It is not the ideal of a substantive moral order, even less of an order of ends for the good life. Human beings join civil society for its usefulness in providing protection for their (pre-social) rights. ${ }^{118}$

In civil society, the enforcement of these rights is the monopoly of the magistrates; that is, public power. But in the international realm exemplified by the high seas, there is no such public power. Thus, although natural rights are also valid in the state of nature, they can only be enforced there by the right-holders themselves: '[A] private war is undertaken justly in so far as judicial recourse is lacking.' ${ }^{119}$ An individual's right had four aspects: the right of self-defence, the right to reparation for damage to person, the right to reparation for damage to goods - and

115 See especially Peter Haggenmacher, 'Droits subjectifs et système juridique chez Grotius' in Luc Foisneau, ed, Politique, droit et théologie chez Bodin, Grotius et Hobbes (Paris: Kimé, 1997) 73.

116 These laws appear twice: first in Grotius, Commentary, supra note 109, ch 2 at 27-9, and again in ibid, Appendix A at 500.

117 Knud Haakonssen, 'Hugo Grotius and the History of Political Thought' in Haakonssen, Modern Natural Law, supra note 111 at 38.

118 See further, Brett, 'Natural Right and Civil Community,' supra note 111.

119 Grotius, Commentary, supra note 109, ch 8 at 142. 
crucially, the right to punish the wrong-doer. In the world outside civil society, a world governed by natural rights, even penal law is relegated to commutative justice. Even punishment is in the hands of the rightholder. $^{120}$ The VOC was, then, entitled to wage war against the Portuguese in self-defence and to receive the booty it had acquired as, in part, reparation, in part, punishment. Moreover, in seeking to break the Iberian monopoly, the Dutch were supporting the interests of commerce and exchange - interests with respect to which humanity was united. ${ }^{121}$ Their war was thus on behalf of humanity itself.

In the history of natural law, Grotius's position as straddling tradition and novelty is a commonplace. But a wide consensus seems to be emerging that he "extracts from Scholastic views on natural law and moral theology the essential points that are relevant to moral and political philosophy.' ${ }^{122}$ As Tierney observes, reading Grotius 'one seems to be reading Suárez transposed to a different idiom. ${ }^{123}$ There are many differences between the scholastics and Grotius in sources and styles of argument. Nevertheless, they share the narrative of the contractual emergence of dominium out of common property, and found their analyses very largely on the search for commutative justice between individual rightholders. And they, of course, assume that this frame is valid universally, irrespective of cultural or religious distinctions. In other words, they react to the expansion of trade and commerce by producing a legal and political vocabulary that takes that expansion as largely natural and articulates the social world created through it as a universal network of inter-individual relations.

In the sixteenth and seventeenth centuries, however, Spanish imperialism emerged from the exercise of public power by the ruler of Castile - at one point, the head of the Holy Roman Empire - in the form of conquest and settlement, administration, and the conduct of mercantilist policies that ultimately failed to sustain Spain's imperial ambitions or even the position of Spain among the European empires. Spain was followed by the Netherlands and England (with a brief French interlude), which understood the importance of the distinctions

120 Haggenmacher, supra note 115.

121 Grotius, Commentary, supra note 109, ch 12 at 303.

122 Terence Irwin, The Development of Ethics: A Historical and Critical Study, vol 2 (Oxford: Oxford University Press, 2008) at 96, 98.

123 Brian Tierney, The Idea of Natural Rights: Studies on Natural Rights, Natural Law, and Church Law 1150-1625 (Grand Rapids, MI: William P Eerdmans Publishing, 1997) at 316. 
concocted by the School of Salamanca; their imperialism was the imperialism of free trade, carried out by private companies through private transactions and private war. Public resources would not be wasted when private operators could be liberated to carry out the work of disciplining the natives through commerce and the extraction of resources. In due course, the fact that all dominium originally had to do with humans' exercising power of over humans was forgotten, and the distinction between the two realms of the public and the private was overlaid by other distinctions, such as those between constraint and freedom, regulation and spontaneity, and perhaps, simply old-fashioned and modern.

There is no doubt on which side imperialism has gained its greatest victories: since decolonization, Western domination of the "people without history' has returned to its classical mainstay, informal empire, the creation of wealth and influence and the distribution of material and spiritual resources through the exercise of private power. Today's ius gentium continues to be divided into the law of treaties, on the one side, and the law of contract, on the other. There is no doubt on which side the most significant aspect of dominium - that is, the power of human beings over other human beings - is exercised. It is a great paradox that Spanish political leaders never really understood that this was what their brightest thinkers were prophesying. 